\title{
Severe meprobamate poisoning: successful treatment with haemoperfusion
}

\author{
Peter Crome \\ M.B., M.R.C.P.
}

\author{
T. HiggenbotTOM \\ B.Sc., M.B., M.R.C.P.
}

\author{
J. A. ElliotT* \\ B.Sc., M.B., M.R.C.P. \\ Guy's Hospital, London SEI 9RT, and *Department of Thoracic Medicine, \\ St James' Hospital, London SE12 $8 \mathrm{HW}$
}

\begin{abstract}
Summary
Charcoal haemoperfusion used to treat a 56-year-old woman who had taken a very large overdose of meprobamate was followed by full recovery. The plasma clearance of meprobamate was $153 \mathrm{ml} / \mathrm{min}$ and this compares favourably with values obtained for haemodialysis. The indications for haemoperfusion are reviewed.
\end{abstract}

\section{Introduction}

Severe meprobamate poisoning is uncommon in this country, only nine deaths being attributed to this drug in 1974 (Office of Population, Censuses and Surveys, 1976). The clinical features resemble those seen after an oversose of barbiturates but as meprobamate is rapidly metabolized coma rarely lasts for more than $24 \mathrm{hr}$. Plasma meprobamate concentrations above $100 \mathrm{mg} / \mathrm{l}$ are associated with deep coma (Maddox and Bloomer, 1967) and in a series of fatal meprobamate poisonings the mean plasma meprobamate concentration was found to be $239 \mathrm{mg} / \mathrm{l}$ (Felby, 1970). The case history is reported of a severely poisoned patient with an initial plasma meprobamate level of $260 \mathrm{mg} / \mathrm{l}$ who recovered completely after charcoal haemoperfusion, a technique which has previously been reported by the authors for severe barbiturate, glutethimide, salicylate and paraquat poisoning (Vale et al., 1977; Volans $\epsilon t$ al., 1977).

\section{Case history}

The patient, a 56-year-old woman, was admitted to St James' Hospital, Balham, having been found unconscious at home. She had a long history of depression, including treatment with electro-convulsive therapy and she had previously been prescribed meprobamate and tricyclic antidepressants.
On arrival at hospital she was drowsy, but responded to oral commands, and her blood pressure and respiratory rate were normal. In view of the history and physical findings a diagnosis of selfpoisoning was made. After approximately $9 \mathrm{hr}$ her degree of coma deepened such that she was unresponsive to maximal painful stimuli. Her bloog pressure fell to $80 / 50 \mathrm{mmHg}(10 \cdot 6 / 6.7 \mathrm{kPa})$ but het respiratory rate did not change. In the following $24 \mathrm{hr}$ there was no improvement in her clinica condition. At this stage the results of analyses oo blood and urine samples taken that morning were available, and these revealed a plasma meprobamate level of $260 \mathrm{mg} / \mathrm{l}$ (Flanagan and Berry, 1977) and the presence of tricyclic antidepressants. In view of this extremely high level and the failure of her condition to improve with supportive care she was transferred to Guy's Hospital for haemoperfusion therapy.

After arrival she was found to be in Grade IV coma (Matthew and Lawson, 1975) with bilaterally reduced tendon reflexes. Both her pupils responded to light, she exhibited a divergent gaze and oculocephalic and caloric reflexes were atsent, these signs suggested a severe metabolic cause for her coma (Plum and Posner, 1972). She was maintaining spontaneous respiration, but this was considered clinically to be of small tidal volume and reduced $\subseteq$ rate. The chest radiograph showed bilateral linear atelectasis and her arterial blood gases, while breathing $40 \%$ oxygen, were $\mathrm{pH} 7 \cdot 38, \mathrm{P}_{\mathrm{a}} \mathrm{O}_{2} 58 \mathrm{~N}$ $\mathrm{mmHg}(7.7 \mathrm{kPa}), \mathrm{PaCO}_{2} 41 \mathrm{mmHg}(5.5 \mathrm{kPa})$ and a bicarbonate of $22 \mathrm{mmol} / \mathrm{l}$. These clinical findings $N$ were considered to indicate a severe state of re- $\underset{\omega}{N}$ spiratory depression which had resulted in secondary $\tilde{O}$ changes in her lungs. Assisted ventilation was therefore started.

An arterio-venous shunt was inserted in the arm $\stackrel{\mathscr{D}}{+}$ and $33 \mathrm{hr}$ from her initial hospital admission 
haemoperfusion was started. This was continued for $4 \mathrm{hr}$ using a commercially available acrylic hydrogel coated activated charcoal column.* Within $30 \mathrm{~min}$ of starting haemoperfusion she was responding to oral commands and when it was discontinued after $4 \mathrm{hr}$ she was awake and breathing spontaneously with a $\mathrm{P}_{\mathrm{a}} \mathrm{O}_{2}$ of $156 \mathrm{mmHg}(20.8 \mathrm{kPa})$ and a $\mathrm{P}_{\mathrm{aCO}}$ of $44 \mathrm{mmHg}(5.9 \mathrm{kPa})$ on $60 \%$ oxygen. Her chest radiograph was now clear and she was transferred back to St James' Hospital the next day.

Subsequent toxicological analyses relvealed amitriptyline and nortriptyline concentrations of $88.5 \mu \mathrm{g} / \mathrm{l}$ and $14 \mu \mathrm{g} / \mathrm{l}$ respectively. These were within the therapeutic range. The immediate pre-perfusion plasma meprobamate concentration however was $97 \mathrm{mg} / \mathrm{l}$ and after perfusion this figure had fallen to $62 \mathrm{mg} / \mathrm{l}$. The calculated mean clearance of meprobamate by the column was $153 \mathrm{ml} / \mathrm{min}$ at a flow rate of $300 \mathrm{ml} / \mathrm{min}$.

\section{Discussion}

This case has been reported because it is the first severe meprobamate poisoning which has been managed using charcoal haemoperfusion.

The authors considered haemoperfusion was necessary because of the high initial plasma level and the severity of the patient's coma, as judged by the absence of response to noxious stimuli and the loss of brain stem reflexes, together with the signs of depressed respiration.

It might be argued that after this patient had survived for $33 \mathrm{hr}$ and the plasma level had by then fallen to $97 \mathrm{mg} / \mathrm{l}$ that she could have recovered without ancillary aid. But clinically the response to haemoperfusion was very rapid, a finding Rosenbaum, Kramer and Raja (1976) have reported with overdoses treated with resin haemoperfusion. During the 4-hr spell of haemoperfusion it was estimated, on the basis of plasma concentrations, that over $4 \mathrm{~g}$

\footnotetext{
*Haemocol, Smith and Nephew Pharmaceuticals Ltd, Welwyn Garden City, Herts.
}

of meprobamate were removed from the blood compared with only $2 \mathrm{~g}$ recovered in the urine over a 36-hr period starting $12 \mathrm{hr}$ before the commencement of haemoperfusion.

There is a small group of severely poisoned patients who, having taken sedative drugs, present in a profound state of coma. This may be associated with loss of brain stem reflexes, depression of respiration and loss of autonomic vascular control. In these patients active removal of the drug is indicated when supportive measures are not successful, or if respiratory complications develop.

\section{Acknowledgments}

We would like to thank Mr M. Bewick for inserting the arterio-venous shunt.

\section{References}

FELBY, S. (1970) Concentration of meprobamate in the blood and liver following fatal meprobamate poisoning. Acta pharmacologica et toxicologica, 28, 334.

Flanagan, R.J. \& BeRRY, D.J. (1977) Routine analysis of barbiturates and some other hypnotic drugs in the blood plasma as an aid to the diagnosis of acute poisoning. Journal of Chromatography, 131, 131.

MAdDoX, R.K. \& Bloomer, H.A. (1967) Meprobamate overdosage. Evaluation of its severity and method of treatment. Journal of the American Medical Association, 201, 999.

Mathew, H. \& Lawson, A.A.H. (1975) Treatment of Common Acute Poisonings, p. 18. Churchill Livingstone, Edinburgh.

OfFice of Population, Censuses and SuRveys (1976) Deaths from Poisonous Solids and Liquids-England and Wales. H.M. Stationery Office, London.

Plum, F. \& POSNER, J.B. (1972) Diagnosis of Stupor and Coma, p. 158. Davis, Philadelphia.

Rosenbaum, J.L., Kramer, M.S. \& Raja, R. (1976) Resin hemoperfusion for acute drug intoxication. Archives of Internal Medicine, 136, 263.

Vale, J.A., Crome, P., Volans, G.N., Widdop, B. \& Goulding, R. (1977) The use of oral adsorbents and charcoal haemoperfusion in paraquat poisoning. Acta pharmacologica et toxicologica, 41 (Suppl. 11), 109.

Volans, G.N., Vale, J.A., Crome, P., Widdop, B. \& GouldING, R. (1977) The role of charcoal haemoperfusion in the management of acute poisoning by drugs. In: Strathclyde Bioengineering Seminars-Artificial Organs (Ed. by R. M. Kenedi, J. M. Courtney, J. D. S. Gaylor and T. Gilchrist), p. 178. MacMillan. 